\title{
Quality assessment of rice seed using different storage techniques
}

\author{
S. Chowdhury ${ }^{2}$, M. A. H Chowdhury ${ }^{1^{*}}$, S. Bhattacherjee ${ }^{1}$ and K. Ghosh ${ }^{1}$ \\ ${ }^{1}$ Department of Agricultural Chemistry, Bangladesh Agricultural University, Mymensingh-2202 and ${ }^{2}$ Micro-credit \\ Regulatory Authority, Bank and Financial Division, Ministry of Finance, Dhaka, Bangladesh \\ *E-mail: akhterbau11@gmail.com
}

\begin{abstract}
Rice (cv. BRRI Dhan28) seed from two sources (Farmer and BADC) were collected and stored in 10 different types of indigenous storage containers viz., i) earthen jar (EJ), ii) coaltar coated EJ, iii) seed mixed with neem leaves (Azedirecta indica) in EJ, iv) seed mixed with Biskatali leaves (Polygonum hydropiper) in EJ, v) biscuit tin, vi) drum, vii) hessian bag (HB), viii) hessian bag with polythene cover, ix) dole and $\mathrm{x}$ ) cowdung coated dole for four months in the laboratory of the department of Agricultural Chemistry, Bangladesh Agricultural University, Mymensingh. The changes of some quality components of seed such as moisture content, germination, insect and pathogen attack, protein and starch contents were monitored at certain interval over 120 days of storage. Containers were characterized into three categories viz., easily permeable, permeable and almost impermeable. In case of almost impermeable containers like biscuit tin, drum and hessian bag with polythene cover, seed moisture increased significantly with the advancement of storage period but did not exceed desired level. Moisture percentage of the seeds of biscuit tin, drum and hessian bag with polythene cover was $12.78,12.95$ and $12.88 \%$, respectively. Germination percentage of seeds in all impermeable containers was above $80 \%$. Seed mortality was found to be positively correlated with moisture content and storage duration. Seed borne pathogens were associated along with the seed. Field fungi like Alternaria, Curvularia, Cladosporium though observed initially, but in the last pathological test Aspergillus sp., Penicillium sp. and Fusarium sp. were found predominantly. Insect attack was severe in easily permeable containers. Permeable containers containing the leaves of neem and biskatali restricted insect and fungal attack. Seed protein and starch content varied with storage period. Starch content of seed was $77 \%$ at 60 days of storage and decreased to $75 \%$ at 120 days of storage. Significant superiority of BADC seed over the farmers' seed irrespective of all the parameters studied was noticed. The overall observation suggests that, biscuit tin and drum could be used for small scale storage and hessian bag with polythene cover for bulk storage of rice seed for a certain period.
\end{abstract}

Keywords: Quality, Rice seed, Farmer, BADC, Storage technique

\section{Introduction}

Government of Bangladesh can neither ensure sufficient storage facilities particularly in the rural areas nor supply certified seeds of rice during planting time. It is reported that, only $3 \%$ rice seed are produced and distributed by the government through Bangladesh Agriculture Development Corporation (BADC) and the rest $97 \%$ seeds come from farmers source (BADC, 2001). For that reason, farmers are compelled to store some of their previous harvest as seed in the indigenous containers available at their home or farm. The reason for quick deterioration of seed quality was little investigated in Bangladesh. Moisture absorption by seed at high temperature during storage was reported as the prime cause of seed deterioration in most of the studies. High moisture content of seed was found to affect germination, insect infestation; and purity percentage of seed (Huda, 1992). But none of the reports identified the major fungal and insect species responsible for seed deterioration. Besides, seed quality in terms of protein and starch degradation is yet to be investigated. Generally low cost and easily available materials are used as storage containers. The farmers have been using different types of storage containers over the years in order to protect the seed from moisture absorption (Chowdhury et al., 1990). The environment within different type of permeable and impermeable containers has not been well studied. The scientific research in this area may provide desirable information will help to determine the extent to which farmers need help for ensuring the availability of quality seed for their use within their ability. A study was, therefore, undertaken to evaluate the physico-chemical and biological changes in farmers rice seed compared with certified seed stored in different storage techniques. 


\section{Materials and Methods}

An experiment was laid out in complete randomized design (CRD) in the laboratory of the department of Agricultural Chemistry, Bangladesh Agricultural University, Mymensingh for 120 days (June to September).

One kilogram rice seed cv. BRRI dhan28 from two sources (farmer and BADC) was stored in each container on $1^{\text {st }}$ June, 2001. Initial moisture and germination percentage were $12.3 \& 95$, respectively for farmer's seed and $11.6 \& 97 \%$, respectively for BADC seed. There were ten different storage containers which have been considered as a treatment, are as follows:

1. Earthen jar (EJ)

2. Coaltar coated EJ

3. Seed mixed with leaves of neem (Azedirecta indica) in EJ

4. Seed mixed with leaves of Biskatali (Polygonum hydropiper) in EJ

5. Biscuit tin

6. Drum

7. Hessain bag $(\mathrm{HB})$

8. HB with polythene cover ( $0.1 \mathrm{~mm}$ thick)

9. Dole

10. Cowdung coated dole

Moisture content was determined by universal type moisture meter made by Oriental Science Apparatus Workshop, India. Germination test was conducted as standard germination testing method (ISTA, 1985). For analysing the incidence of seed borne pathogen in seeds, Blotter Incubation Test (BIT) was conducted. Presence or absence of insect, number of insect bitten seed and number of seed having spot were counted by direct examination of seed. Total $\mathrm{N}$ was determined by Micro-kjeldahl method (Page et al., 1982). The protein content of the grain sample was determined by multiplying the total nitrogen (N) by the coefficient 5.85 (PCARR, 1980). The starch content of the grain samples was determined by colorimetric method employing anthrone $\left(\mathrm{C}_{14} \mathrm{H}_{10} \mathrm{O}\right)$ reagent outlined by Clegg (1956).

\section{Statistical analysis}

The data were statistically analyzed using MSTAT statistical package programme. The mean was calculated and analysis of variance was performed by F-Variance test. The significance of differences between pairs of treatment means was evaluated by the least significance difference (LSD) test at $1 \%$ level of probability (Gomez and Gomez, 1984).

\section{Results and Discussion}

The storage environment of ten containers have been grouped into three categories viz., easily permeable, permeable and almost impermeable. Environments of Dole, cowdung coated Dole and hessian bag were easily permeable due to very poor moisture resistance by seed and high moisture permeability by environments. earthen jar, coaltar coated EJ., seed mixed with neem leaves in EJ., seed mixed with leaves of biskatali in EJ were permeable due to poor moisture resistance and poor degree of humidity resistance by the environment. The environment of biscuit tin, drum and hessian bag with polythene cover is totally impermeable containers.

\section{Moisture content}

Storage container significantly affected the moisture content of rice seed. The highest moisture content $(15.46 \%)$ of rice seed was recorded in seeds stored in dole while the lowest moisture content $(12.78 \%)$ was recorded in farmer's seeds stored in biscuit tin (Table 1). It was also observed that earthen jar (13.94 $\%)$, coaltar coated EJ (13.94 \%) maintained statistical identity and performed better than Dole (15.46 \%) for rice seeds. Moisture content of seed stored in drum (12.95\%) and hessian bag with polythene cover $(12.88 \%)$ were identical to that of biscuit tin. On the other hand, moisture content of seed stored in hessian bag (HB) and cowdung coated dole were 14.59 and $14.99 \%$, respectively. Observations of 
Chowdhury et al. (1990) and Janmejai et al. (1999) are also in agreement with these findings that moisture proof containers are most suitable for storage of lentil seeds particularly those covered or made by polyethylene. Storage of seeds in biscuit tins showed only a $0.25 \%$ increase in seed moisture content (Janmejai et al., 1999).

The results presented in Table 2 shows that, the moisture content of the seed responded significantly to the storage period. Farmer's seed absorbed highest amount of moisture (15.06\%) after 120 days of storage. After 60 and 90 days of storage, the moisture content was 13.92 and $14.64 \%$, respectively. It appeared that, though with the advancement of storage period the moisture content of the seeds significantly increased but decreased at 90 days of storage period because at that time environmental humidity was above $96 \%$ (data not shown). Seed moisture content was also reported to increase with increasing storage duration in all packing except tin cans for maize and sorghum (Thai, 1981).

Table 1. Effect of storage container on the moisture content and germination of rice seed cv. BRRI dhan28

\begin{tabular}{|c|c|c|c|c|}
\hline \multirow[t]{2}{*}{ Storage container } & \multicolumn{2}{|c|}{ Moisture content (\%) } & \multicolumn{2}{|c|}{ Germination (\%) } \\
\hline & Farmer & BADC & Farmer & BADC \\
\hline Earthen jar (EJ) & 13.94 & 13.33 & 63 & 66 \\
\hline Coalter Coated EJ & 13.94 & 13.67 & 69 & 76 \\
\hline Seed mixed Neem in EJ & 13.50 & 13.21 & 77 & 80 \\
\hline Seed mixed with Biskatali in EJ & 13.65 & 13.24 & 74 & 80 \\
\hline Biscuit tin & 12.78 & 12.51 & 87 & 92 \\
\hline Drum & 12.95 & 12.50 & 81 & 90 \\
\hline Hessian bag (HB) & 14.59 & 13.35 & 58 & 72 \\
\hline HB with polythene cover & 12.88 & 12.43 & 85 & 86 \\
\hline Dole & 15.46 & 15.00 & 56 & 60 \\
\hline Cowdung coated Dole & 14.99 & 14.55 & 60 & 75 \\
\hline LSD (0.01) & 0.45 & 0.40 & 5.6 & 5.2 \\
\hline
\end{tabular}

Table 2. Effect of storage period on the moisture content and germination of rice seed cv. BRRI dhan28

\begin{tabular}{|l|c|c|c|c|}
\hline \multirow{2}{*}{ Storage period } & \multicolumn{2}{|c|}{ Moisture content (\%) } & \multicolumn{2}{c|}{ Germination (\%) } \\
\cline { 2 - 5 } & Farmer & BADC & Farmer & BADC \\
\hline Day 15 & 13.27 & 13.15 & 90 & 93 \\
\hline Day 30 & 13.85 & 13.38 & 84 & 91 \\
\hline Day 45 & 13.56 & 13.42 & 81 & 85 \\
\hline Day 60 & 13.92 & 13.73 & 81 & 84 \\
\hline Day 75 & 13.73 & 13.70 & 69 & 77 \\
\hline Day 90 & 14.64 & 14.19 & 67 & 71 \\
\hline Day 105 & 14.63 & 14.20 & 66 & 61 \\
\hline Day 120 & 15.06 & 14.88 & 59 & 52 \\
\hline LSD (0.01) & 0.22 & 0.17 & 5.5 & 5.1 \\
\hline
\end{tabular}

Interaction effect of storage container and storage period on the moisture content of seed have been graphically represented (Fig. 1). The lowest moisture content was observed in the seeds stored in the Biscuit tin (12.9\%) during the same storage period. This was statistically identical to the moisture content of seeds stored in drum and HB with polythene cover. BADC seed moisture content was lower than farmer's seed (Table 1 and Table 2).

\section{Germination}

Storage containers had a significant effect on the germination percentage of rice seed (Table 1). The highest percentage of germination of farmer's seed was observed in biscuit tin (87\%) followed by HB with polythene cover (85 \%) and drum (81\%). EJ with neem leaves (77\%), EJ with biskatali leaves (74\%), and coalter coated EJ (69\%), showed moderate germination capacity. But rest of the four containers had low 
germinability. None of the containers could cause complete seed mortality. It can be seen from Table 1 , seed preserved in impermeable containers maintained acceptable seed viability. In case of certified seed, all the containers showed standard seed germination percentage except easily permeable containers (Table 1). Seeds kept in impermeable and permeable containers showed different germinability. Container when made restrictive to air passage (impermeable) helped in keeping germination percentage higher than permeable and easily permeable conditions. It is recommended that seed should be stored in moisture proof containers (Sangakkara and Somaratne, 1988).

Storage period was found to be significant on germination percentage of seed (Table 2). After 15 days of storage, farmer's seed showed the highest germination percentage (90\%). Between 30 and 60 days of storage, germination was almost similar (84\% and 81\%). The lowest germination (59\%) was recorded at the end of the storage period. Germination percentage showed a decreasing trend with extending storage period. Germination capacity decreased slowly in early days of storage but in later part of storage, it went down more rapidly to the lowest (15\%). The observation is in agreement with that of Balma (1988). The seed mortality might be due to the increased accumulation of moisture in seeds (Fig. 1), high relative humidity and temperature prevailing during the storage period. Improper storage may result destruction of vigour or even complete loss of viability (Hossain, 1978).

After 120 days of storage period, seed viability were lowest in $\mathrm{HB}$, dole and cowdung coated dole. The lowest germination percentage of all the containers of farmers and BADC seed resulted at the final sampling date (Fig. 2). The result of the experiment clearly indicates that environment of biscuit tin, HB with polythene cover and drum were superior to other storage containers. They maintained lower moisture content and relative humidity during the storage period.

Chickpea seed was stored for 7 months in 3 different containers: kangi (local bin), kangi with plastic lining and jute bag. The seed stored in kangi with plastic lining showed lower moisture content and higher germination rate than the jute bag after 210 days storage (Kenghe et al., 1992).

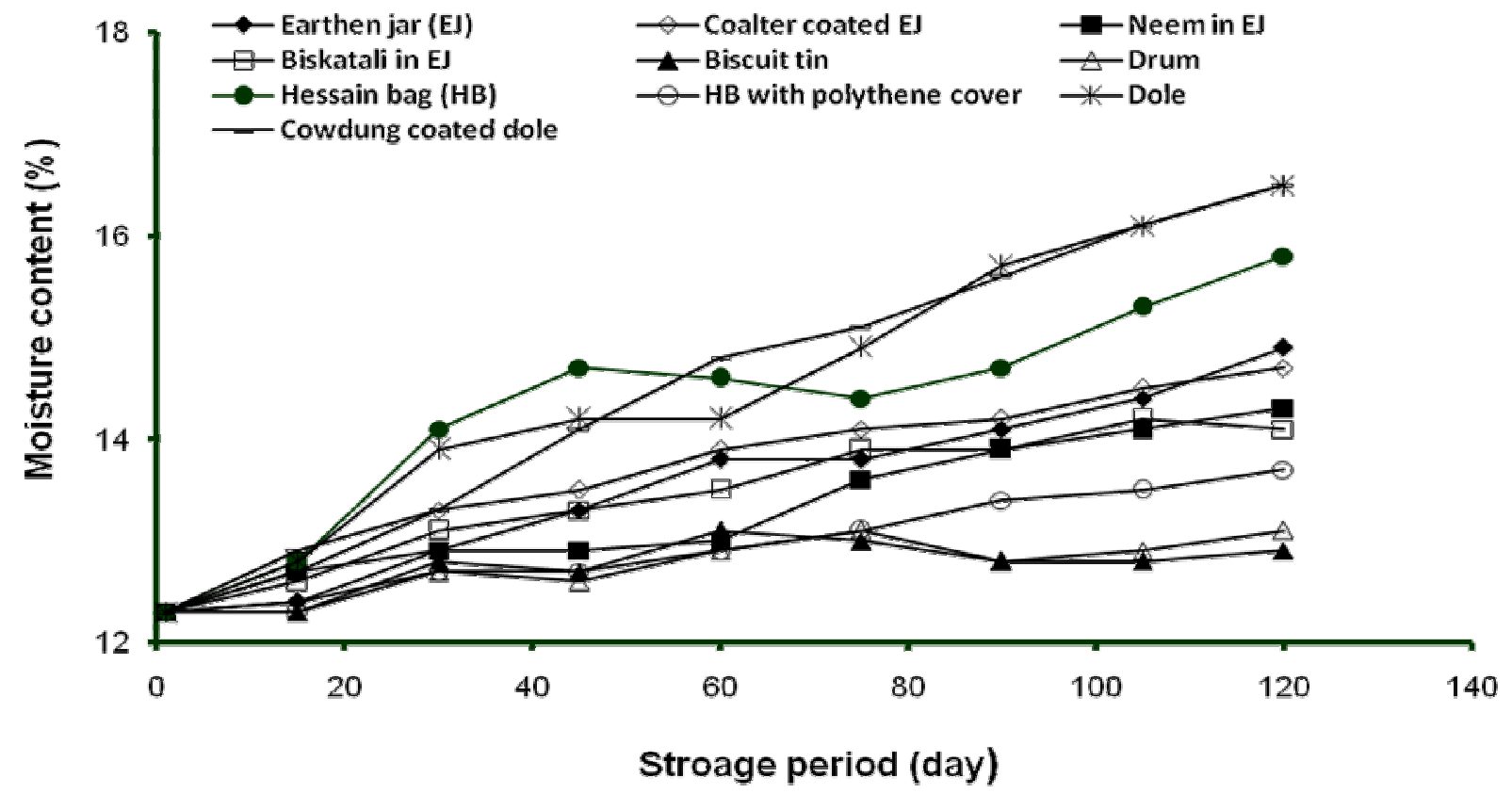

Fig. 1. Moisture accumulation in the farmers' rice seed cv. BRRI Dhan 28 stored in different containers with the advancement of storage period 


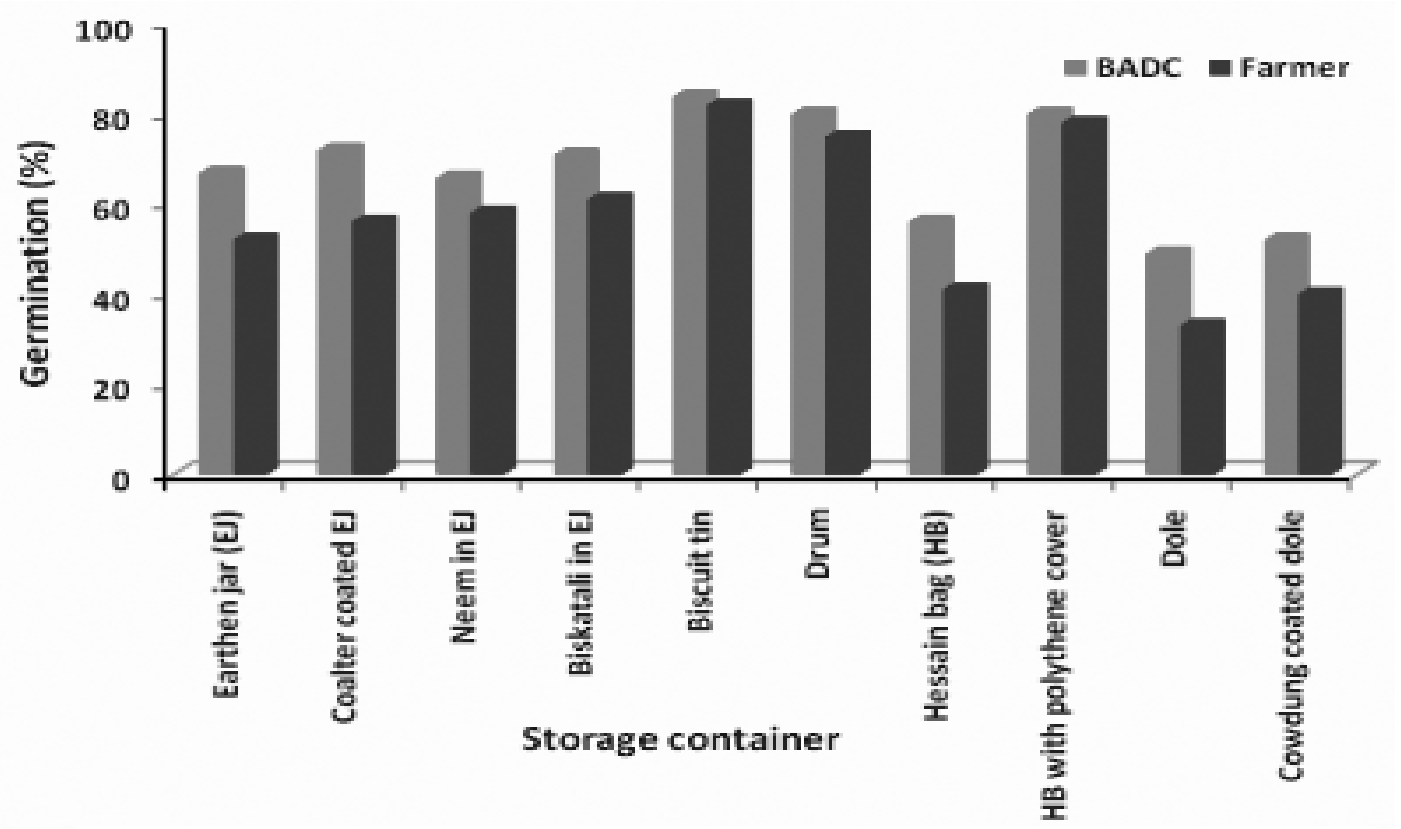

Fig. 2. Effect of storage container on the germination of BADC and farmer's rice seed cv. BRRI dhan28 at 120 days of storage

\section{Fungal infection}

Mean numbers of pathogen presented in the samples kept in different containers are shown in Table 3a. Differences in the mean numbers of pathogens were noticed among the containers. Twelve types of fungus i.e. Bipolaris oryzae, Alternaria padwickii, Fusarium moniliforme, Fusarium sp., Pyricularia oryzae, Curvularia lunata, Alternaria solani, Aspergillus flavus, A. niger, Penicillium sp. Rhizopus were identified from rice seeds at 120 days of storage period. Some pathogenic fungi such as, Aspergillus flavus, $A$. niger, and Penicillium sp. increased with the advancement of time. Non permeable and permeable containers where moisture content of seed was less than the easily permeable containers, storage fungi mainly Aspergillus and Penicillium sp. developed on seeds with $12-18 \%$ moisture content (FAO, 1985).

Table 3a. Predominant fungi (\%) associated with rice seed samples of different storage containers collected at $\mathbf{1 2 0}$ days of storage period

\begin{tabular}{|c|c|c|c|c|c|c|c|c|c|c|c|c|c|c|c|c|c|c|c|c|}
\hline \multirow{3}{*}{ Pathogen } & \multicolumn{20}{|c|}{ Container } \\
\hline & \multicolumn{2}{|c|}{$\begin{array}{l}\text { Earthen Jar } \\
\text { (EJ) }\end{array}$} & \multicolumn{2}{|c|}{$\begin{array}{c}\text { Coalter } \\
\text { coated EJ }\end{array}$} & \multicolumn{2}{|c|}{$\begin{array}{l}\text { Seed } \\
\text { mixed with } \\
\text { neem in EJ }\end{array}$} & \multicolumn{2}{|c|}{$\begin{array}{c}\text { Seed } \\
\text { mixed with } \\
\text { biskatali in } \\
\text { EJ }\end{array}$} & \multicolumn{2}{|c|}{ Biscuit tin } & \multicolumn{2}{|c|}{ Drum } & \multicolumn{2}{|c|}{$\begin{array}{l}\text { Hessian } \\
\text { bag (HB) }\end{array}$} & \multicolumn{2}{|c|}{$\begin{array}{c}\text { HB with } \\
\text { polythene } \\
\text { cover }\end{array}$} & \multicolumn{2}{|c|}{ Dole } & \multicolumn{2}{|c|}{$\begin{array}{c}\text { Cowdung } \\
\text { coated } \\
\text { dole }\end{array}$} \\
\hline & $F$ & B & $F$ & B & $F$ & B & $\mathrm{F}$ & B & $\mathrm{F}$ & B & $F$ & B & $\mathrm{F}$ & B & $\mathrm{F}$ & B & $F$ & B & $F$ & B \\
\hline Bipolaris oryzae & 24 & 2.2 & 27 & 2.5 & 3.0 & 2.5 & 3.5 & 3.0 & 7.5 & 6.5 & 8.5 & 7.0 & 20 & 18.5 & 9.0 & 8.5 & 15.0 & 14.5 & 12.0 & 11.5 \\
\hline Alternaria padwic & 3.5 & 2.5 & 3.0 & 2.0 & 2.0 & 1.5 & 2.0 & 1.5 & 3.0 & 2.0 & 3.0 & 2.5 & 7.0 & 6.5 & 3.5 & 3.0 & 4.5 & 4.0 & 3.5 & 3.0 \\
\hline \begin{tabular}{|l|} 
Fusarium \\
moniliforme
\end{tabular} & 1.5 & 1.5 & 2.5 & 2.0 & 1. & 1.0 & 1.5 & 2.5 & 2.5 & 3.0 & 3.0 & 4.0 & 6. & 5.0 & 2.5 & 2.0 & 3.0 & 5 & 1.5 & 0 \\
\hline \begin{tabular}{|l|} 
Fusarium oryzae \\
\end{tabular} & 3.5 & 3.5 & 5.0 & 4.0 & 3.0 & 2.5 & 3.5 & 3.0 & 3.0 & 3.0 & 5.0 & 5.0 & 30 & 2.5 & 3.5 & 3.0 & 1.0 & 1.0 & 0.5 & 0.5 \\
\hline Pyricularia oryzae & 1.0 & 0.5 & 1.5 & 1.0 & 1.0 & 0.5 & 2.0 & 1.0 & 2.0 & 1.0 & 2.0 & 1.5 & 3.0 & 2.5 & 1.0 & 0.5 & 2.5 & 1.5 & 2.0 & 1.0 \\
\hline Curvularia sp. & 1.5 & 1.0 & 2.5 & 2.0 & 2. & 1 & 3.0 & 2.5 & 3.0 & 2.0 & 3.0 & 2.5 & 12.0 & 11.0 & 7.0 & 6.5 & 2.0 & 2.0 & 3.0 & 2.0 \\
\hline Curvularia lunata & 20.5 & 18.5 & 22 & 20.5 & 7.0 & 5.5 & 6.0 & 5.5 & 7.0 & 6.0 & 8.0 & 6.5 & 16.5 & 14.5 & 13.0 & 12 & 5.5 & 5.0 & 3.0 & 2.6 \\
\hline Alternaria solani & 3.0 & 2.5 & 2.5 & 2.0 & 3. & 2.5 & 3.0 & 2.0 & 2.0 & 1.5 & 1.5 & 1.0 & 7.5 & 6.5 & 1.5 & 1.5 & 3.5 & 2.5 & 4.0 & 2.0 \\
\hline Aspergillus flavus & 14.5 & 12.5 & 11.0 & 10.5 & 7.0 & 6.5 & 8.0 & 7.5 & 8.5 & 8.0 & 9.0 & 8.5 & 18.0 & 15 & 12.5 & 10.5 & 11.5 & 10.0 & 9.5 & 9.0 \\
\hline Aspergillus niger & 11.0 & 11.0 & 9.0 & 8.5 & 4.0 & 3.5 & 4.5 & 4.5 & 5.5 & 5.0 & 6.5 & 5.5 & 12.0 & 10.5 & 10.0 & 8.5 & 9.0 & 8.0 & 6.5 & 5.0 \\
\hline Penicillium sp. & 9.0 & 8.5 & 7.5 & 7.5 & 5.0 & 4.0 & 5.0 & 4.5 & 5.0 & 4.5 & 5.5 & 5.0 & 11.0 & 9.5 & 9.0 & 6.5 & 7.0 & 5.0 & 4.5 & 4.0 \\
\hline Rhizopus & 5.5 & 5.5 & 5.0 & 5.0 & 3.5 & 3.0 & 4.0 & 3.5 & 3.5 & 3.0 & 5.0 & 4.5 & 3.5 & 2.5 & 3.0 & 2.0 & 3.0 & 2.0 & 1.5 & 1.5 \\
\hline
\end{tabular}




\section{Insect infestation}

At the initial stage, all the samples were free from insect infestation and were not attacked by insects until 75 days of storage. The highest intensity of insect attack was observed in dole where mass Corcyra ceplonica population was found at the end of the storage period. Container wise severity of insect attack of farmers' and certified seed are presented in Table 3b. The traditional storage structures used by the farmers' are frequently of poor construction and vulnerable to rodent and insect attack (Samajpati and Sheikh, 1980).

Table 3b. Predominant insect associated with rice seed samples of different storage containers collected at 120 days of storage period

\begin{tabular}{|c|c|c|c|c|c|c|c|c|c|c|c|c|c|c|c|c|c|c|c|c|}
\hline \multirow{3}{*}{ Insect } & \multicolumn{20}{|c|}{ Container } \\
\hline & \multicolumn{2}{|c|}{$\begin{array}{c}\text { Earthen Jar } \\
(E J)\end{array}$} & \multicolumn{2}{|c|}{$\begin{array}{c}\text { Coalter } \\
\text { coated EJ }\end{array}$} & \multicolumn{2}{|c|}{$\begin{array}{c}\text { Seed mixed } \\
\text { with neem } \\
\text { in } \mathrm{EJ}\end{array}$} & \multicolumn{2}{|c|}{$\begin{array}{c}\text { Seed mixed } \\
\text { with biskatali } \\
\text { in EJ }\end{array}$} & \multicolumn{2}{|c|}{ Biscuit tin } & \multicolumn{2}{|c|}{ Drum } & \multicolumn{2}{|c|}{$\begin{array}{c}\text { Hessian } \\
\text { bag }(\mathrm{HB})\end{array}$} & \multicolumn{2}{|c|}{$\begin{array}{l}\text { HB with } \\
\text { polythene } \\
\text { cover }\end{array}$} & \multicolumn{2}{|c|}{ Dole } & \multicolumn{2}{|c|}{$\begin{array}{l}\text { Cowdung } \\
\text { coated dole }\end{array}$} \\
\hline & $\mathrm{F}$ & $B$ & $\mathrm{~F}$ & $B$ & $\mathrm{~F}$ & $B$ & $\mathrm{~F}$ & B & $F$ & $B$ & $\mathrm{~F}$ & $B$ & $F$ & $B$ & $\mathrm{~F}$ & B & $F$ & $B$ & $\mathrm{~F}$ & $B$ \\
\hline Corcyra cephalonica & $\mathrm{SI}$ & $\mathrm{I}$ & $\mathrm{SI}$ & I & $\mathrm{I}$ & $\mathrm{A}$ & 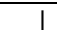 & $\mathrm{A}$ & $\mathrm{A}$ & $A$ & $\mathrm{I}$ & $A$ & $\mathrm{SI}$ & $\mathrm{SI}$ & $\mathrm{A}$ & $\mathrm{A}$ & $\mathrm{SI}$ & $\mathrm{SI}$ & $\mathrm{SI}$ & $T$ \\
\hline
\end{tabular}

Note: $\mathrm{F}=$ Farmers seed; $\mathrm{B}=\mathrm{BADC}$ seed; $\mathrm{I}=$ Infected; $\mathrm{SI}=$ Severely infected

\section{Protein}

Protein content is an important constituent in the nutritional quality of rice seed. The level of protein content of seeds of both farmer and BADC has been presented in Table 4. Effect of storage period on protein percentage was significant. At 30,60, 90 and 120 days of sampling, mean protein content of farmer's seed were $8.77,8.62,8.47$ and $8.15 \%$, respectively. From the result, it is clear that, protein break down increased with the advancement of storage period. BADC seed showed slightly better result because it's genetic purity and drying method were better than that of farmers' seed. These seed showed better physical conditions. As a result total loss of nutrient was low.

Table 4. Effect of storage period on the protein and starch content of rice seed cv. BBRI Dhan28

\begin{tabular}{|l|c|c|c|c|}
\hline \multirow{2}{*}{ Storage period } & \multicolumn{2}{|c|}{ Protein (\%) } & \multicolumn{2}{c|}{ Starch (\%) } \\
\cline { 2 - 5 } & Farmer & BADC & Farmer & BADC \\
\hline Day 30 & 8.77 & 9.21 & 77.58 & 77.86 \\
\hline Day 60 & 8.62 & 8.86 & 76.45 & 77.29 \\
\hline Day 90 & 8.47 & 8.75 & 75.82 & 76.50 \\
\hline Day 120 & 8.15 & 8.42 & 75.08 & 76.26 \\
\hline LSD (0.01) & 0.16 & 0.19 & 0.72 & 0.73 \\
\hline
\end{tabular}

\section{Starch}

Rice is known as cereal starchy food crop. Starch percentage of the seeds of all containers was recorded at every 30 days of interval. Mean starch content of farmer's seed at 30,60, 90 and 120 days of interval were $77.58,76.45,75.82$ and $75.08 \%$, respectively (Table 4). It was an important observation that, the starch contents of BADC seed did not decrease much compared with farmers seed (Fig. 3). The data revealed that, with the advancement of storage period starch break down also increased.

At the storage condition insect and fungal attack increased which deteriorated health status of seed and starch content of those seeds were used by insects and fungi. The fungi caused a significant decrease in the total carbohydrate content of seeds (Purushothan et al., 1996).

From Fig. 3 it is clear that starch break down was lower in BADC seed compared with farmer's seed. In a report, comparative performance of certified seed and farmer's seed of wheat were described. The study revealed a significant superiority of certified seed over the seed of the farmers (Agrawal, 1988). 


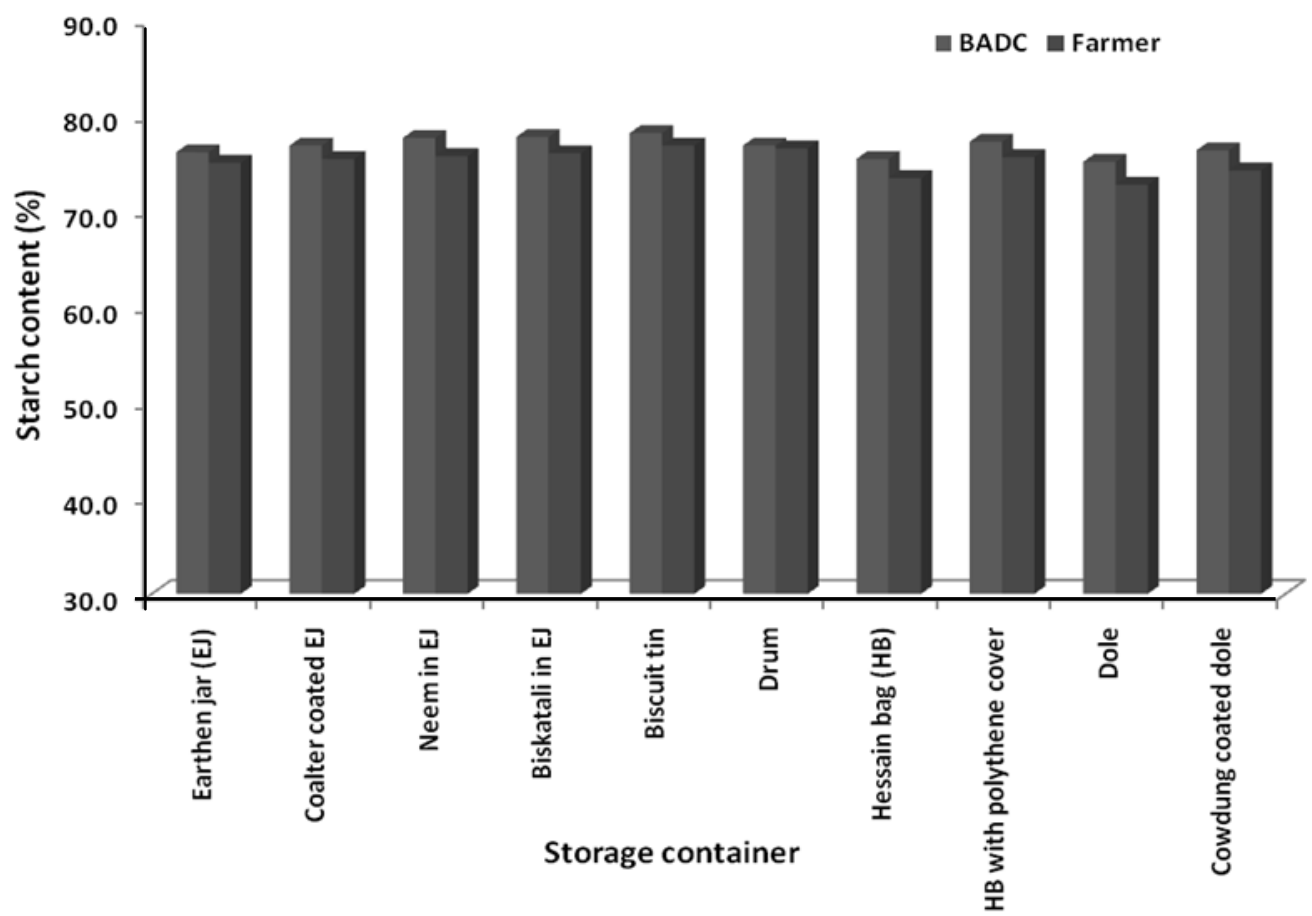

Fig. 3 Effect of storage container on starch content of BADC and farmer's rice seed cv. BRRI dhan28 at 120 days of storage

\section{Correlation studies}

It was found from Fig. 4 that there was a direct significant positive relationship between rice seed mortality and seed moisture having $r=0.95$ with a line of regression having $y=11.584+0.0816 x$. There was also direct significant (positive) relationship between storage duration (days) and seed mortality (\%) of rice which has been confirmed with correlation co-efficient $r=0.98$ (Fig. 5). The relationship was more evident with use of regression equation $y=6.0357+0.2865 x$ and also showing gradual increase in seed mortality with the increase of storage duration.

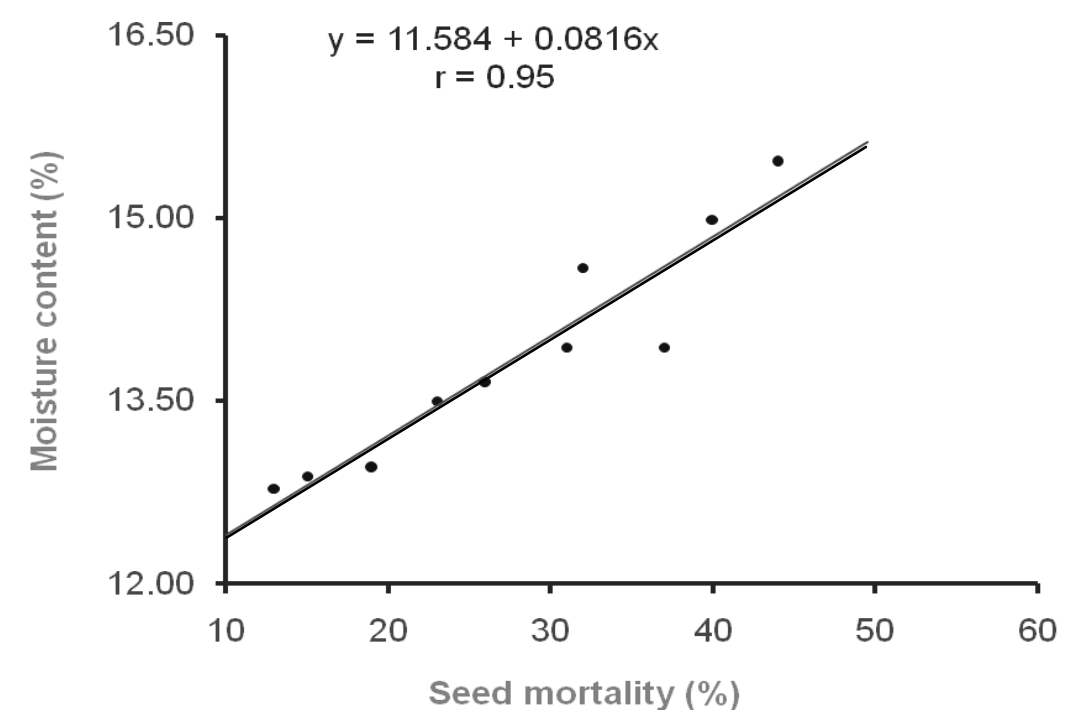

Fig. 4. Correlation and estimated linear regression line between seed mortality and moisture content of rice seed cv. BRRI dhan28 


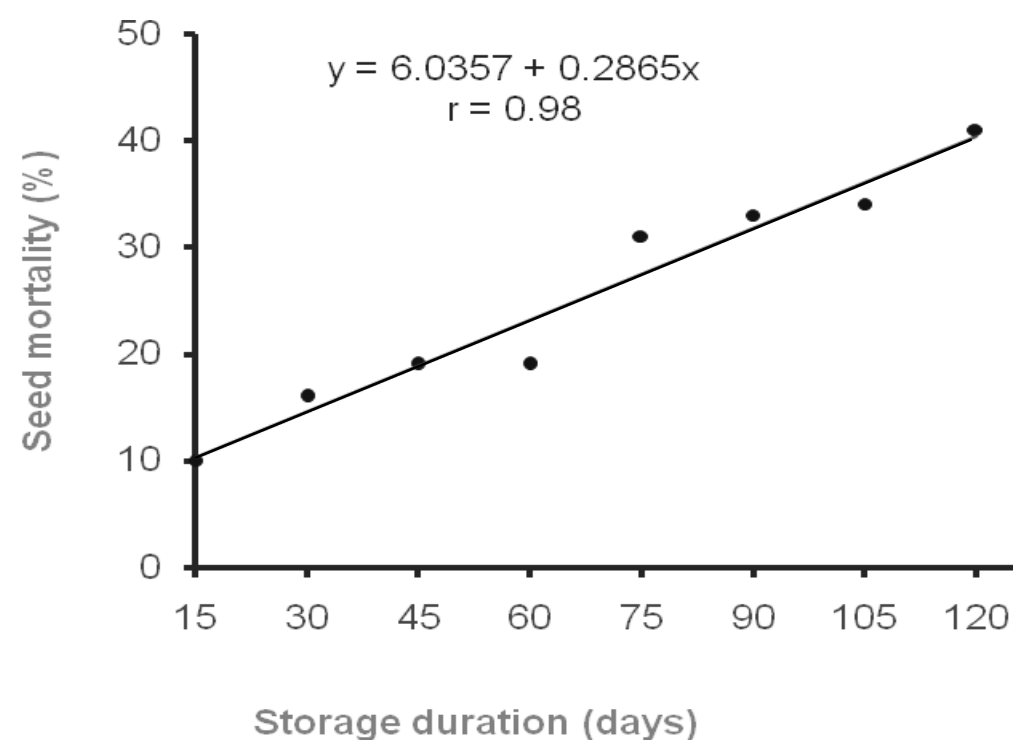

Fig. 5. Correlation and estimated linear regression line between seed mortality and storage duration of rice seed cv. BRRI dhan28

\section{Conclusion}

Seed in all impermeable containers was found having lower moisture content as well as higher germination percentage. Quality of seeds including starch and protein content was deteriorated with the advancement of storage period. Permeable containers enhanced the severity of pest attack whereas use of leaves of neem and biskatali restricted insect and fungal attack. The overall results suggest that biscuit tin and drum can be used for small scale storage and hessian bag with polythene cover for bulk storage of rice seed for a certain period.

\section{Acknowledgements}

The authors are grateful to Ministry of National Science and Technology (NST), Bangladesh Institute of Nuclear Agriculture, Department of Agronomy, Seed Pathology Laboratory and Department of Entomology of Bangladesh Agricultural University, Mymensingh for necessary help.

\section{References}

Agrawal, P.K. 1988. Research Thrusts and Achievement, Division of Seed Science and Technology. Indian Agricultural Research Institute, New Delhi-110012, India. pp. 17-28.

BADC (Bangladesh Agricultural Development Corporation), 2001. Beej Shilpo Unnyon Shirshak Jatia Seminar. BADC Krishibid Samity.

Balma, D. 1988. Study of germination capacity in soybean seeds produced in tropical Africa. Oleagineux. 43(6) : 255-259.

Chowdhury, M.A.H., Hossain, S.M.A. and Talukder, N.M. 1990. Seed quality of lentil as affected by various storage techniques. Prog. Agric., 1(1): 31-37.

Clegg, K.M. 1956. The application of the anthrone reagent to the estimation of starch in Cereals. J. Sci. Fd. Agric., 7: 40-44.

FAO(Food and Agriculture Organization of the United Nations), 1985. Production Yearbook. Food and Agriculture Organization. Rome. 41: 116-117.

Gomez, K.A. and Gomez, A.A. 1984. Statistical Procedures for Agricultural Research. 2nd Edn., John Willey and Sons., New York. pp. 97-111. 
Hossain, S.M.A. 1978. Storage environment of seeds. In: Lecture on Seed Production and Certification. (Hossain, S. M. A. and M. A Hossain ed.) GTI, Bangladesh Agic. Univ. Mymensingh. pp. 87-92.

Huda, N. 1992. Effect of Quality of certified seed and farmers seed on the productivity of rice and wheat. Ph. D. Dept. of Agronomy, Bangladesh Agricultural University, Mymensingh.

ISTA (International Seed Testing Assosiation). 1985. International rules for seed testing. Seed Sci. Technol., 13(2): 309-343.

Janmejai-Tripathi, Powell, A. A. and Tripathi, J. 1999. Influence of seed storage on the delivery of quality seed in the informal sector in Nepal. Proceedings of the 1999 World Seed Conference, Cambridge, UK. pp. 127-137.

Kenghe, R.N., Kanawade, L.R, Salokhe, V.M., Singh, G. and Ilangantileka, S. 1992. Storage studies on Chickpea (Cicer arientian L.) seed. Proc. Inter. Agril. Eng. Con., Bangkok, Thailand. II: 541-547.

Page, A.L., Millar, R.H. and Keeney, D.R., (eds.). 1982. Methods of Soil Analysis, Part-2, American Society of Agronomy, Inc. Madison, Wisconin, 188: 215-221.

PCARR (Philippine Council for Agriculture Resources and Research) 1980. Standard methods of analysis for soil. tissue. Water and fertilizer from Res. Syst. Res. Div. Los Benos, Philippines. pp. 11-72.

Purushotham, S.P., Patkar, K.L., Prakash, H.S and Shetty, H.S. 1996. Storage fungi and their influence on rice seed quality. Indian Phytopathol., 49(2): 152-156.

Samajpati, J.N. and Sheikh, M.S.A. 1980. Paddy and rice storage in Bangladesh with emphasis on insect infestation. Agril. Mech. Asia. pp. 69-72.

Sangakkara, S.R. and Somaratne, H.M. 1988. Sources, storage conditions and quality of mungbean seeds for cultivation in Sri Lanka. Seed-Sci. Tech., 16(1): 5-10.

Thai, T.Y. 1981. The effect of storage conditions on the viability, vigour and storability of maize (Zea mays. L), Sorghum, (Sorghum vulgare L.) and soybean (Glycine max (L) Merrill) seeds. MARDI Res. Bull., 9: 24-34. [Field Crop Abst. 36: 335] 